\title{
RE-NATURALIZATION OF THE CITY OF BARCELONA, SPAIN: INTRODUCING GREENERY IN MEDITERRANEAN BUILDINGS
}

\author{
FABIOLA MEIGNEN, ANNA MARTÍNEZ \& NURIA MARTÍ \\ Department of Architecture, University Ramon Llull, Spain
}

\begin{abstract}
Nowadays, one of the main problems facing the city of Barcelona is climate change, which intensifies the urban heat island effect (UHI), as well as generating high levels of air and noise pollution. These environmental problems have a negative effect on the urban ecosystem and the living standards of its inhabitants. Greenery is able to counteract their effects, by capturing airborne dust, absorbing $\mathrm{CO}_{2}$, thus favouring better thermal regulation, increasing biodiversity and improving the quality of life of the population. This research intends to develop new forms of naturalization in Barcelona, introducing greenery not only in inhabited buildings in order to create long term benefits for the community, but also proposing new ways of constructing on top of the roof tops of existing buildings by means of industrialized attic flats. The majority of these penthouses are located in the Eixample District, the most crowded neighbourhood in the metropolitan area of Barcelona and the district which is probably most exposed to urban pollution. For this reason, the investigation seeks to innovate technical solutions that incorporate vegetation into the architectural projects of La Casa por el Tejado, taking benefit of the available surfaces such as roof-tops and party walls. The article will address different ways to implement greenery in La Casa por el Tejado's projects through modular industrial solutions that require minimum maintenance and provide a study of benefits, opportunities and obstacles found in the application of vegetation, a description of the key factors to overcome these barriers, as well as how the implementation of greenery could introduce positives changes in the living dynamics of people and the city.

Keywords: greenery, vegetation, re-naturalization, intermediate spaces, Barcelona.
\end{abstract}

\section{INTRODUCTION}

Urban centres in Barcelona are characterized for presenting high levels of pollution, which is directly related with the elevated density of the city [1]. The metropolitan area of Barcelona has a population of 1,628,936 inhabitants and a density of $15,944.9 \mathrm{inhab} / \mathrm{km}^{2}$ [2].

During recent years, the levels of particle matter $\left(\mathrm{PM}_{10}\right)$ in the air registered have increased to $56 \mu \mathrm{g} / \mathrm{m}^{3}$ in the metropolitan area of the city, which exceed the reference value established by the European Union $\left(40 \mu \mathrm{g} / \mathrm{m}^{3}\right)$ [3].

In addition, $50 \%$ of the population of the city is exposed to noise levels over $65 \mathrm{~dB}$ and over $66 \%$ of its inhabitants are affected by ozone levels in excess of $180 \mu \mathrm{g} / \mathrm{m}^{3}$, and maximum $\mathrm{NO}_{2}$ levels up to $200 \mu \mathrm{m} / \mathrm{m}^{3}$ [4].

$70 \%$ of the metropolitan area of Barcelona is surfaced with materials (roads, roof tops) that contribute to the urban heat island (UHI) effect, that is to say, they are able to absorb the heat in the day and release it during the night [5].

The air and noise pollution jointly with the heat island effect decrease the quality of life of its inhabitants, affecting their health and comfort. For this reason, Barcelona City Hall is looking for ways to overcome these problems by generating plans, initiatives and subventions that seek to mitigate the negative effects from pollution.

One of them is the Barcelona Biodiversity Plan 2020 [6]. This plan looks to establish a green infrastructure in the city that promotes the regeneration of biodiversity and increases the quality of life of the inhabitants of Barcelona. Greenery plays an important role in this 
plan, since it is an important measure to reduce air and sound pollution and mitigate the effects of urban heat island. This is a new way to understand the implementation of greenery in the city, which is re-naturalizing the existing infrastructures, taking advantage of the existing available surfaces that can adopt vegetation.

\section{CONTEXT}

\subsection{Eixample}

The investigation takes place in the Eixample district which is one of the densest neighborhood in Barcelona. It presents a density of 376 inhab/ha and is 819 ha [7] (Fig. 1). In this district, the highest levels of concentration of particle matters have been registered. In addition, it is the most affected area in the metropolitan city by the heat island effect, the difference in temperature between Eixample and the periphery of the city can be as high as $7.50^{\circ} \mathrm{C}$, and in the rest of the city up to $3^{\circ} \mathrm{C}[8]$.

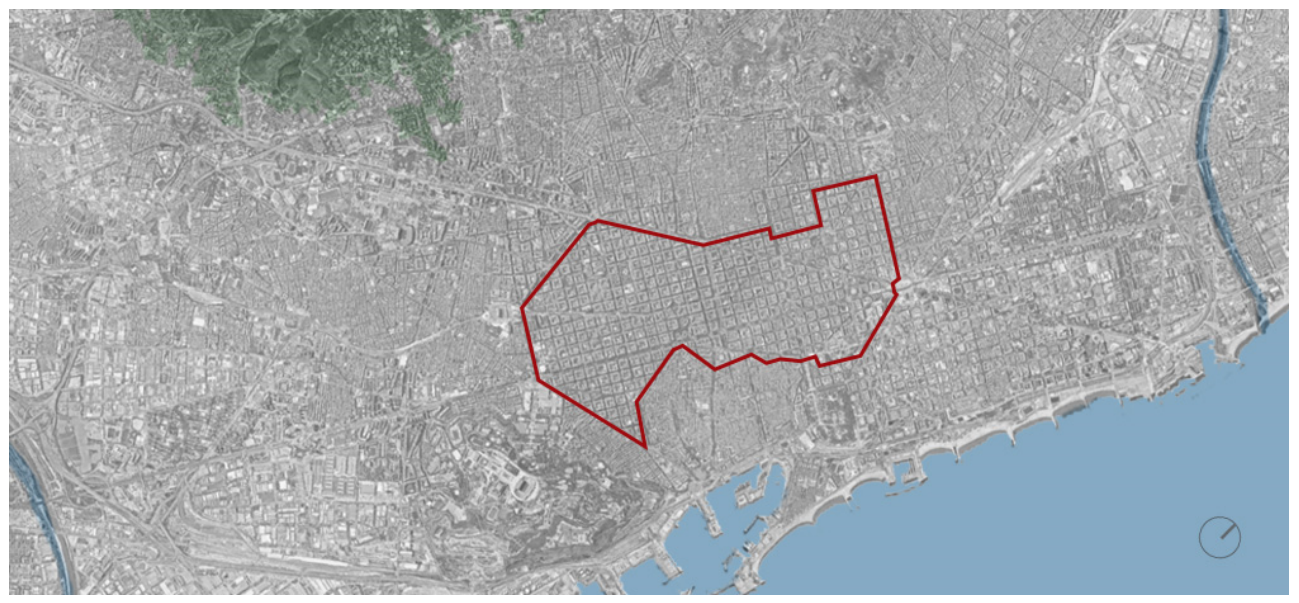

Figure 1: The Eixample district. (Source: F. Meignen, 2019.)

The Eixample district was designed by Ildelfons Cerdà, it is composed of closed blocks with central patios for ventilation and illumination. These blocks are equal in dimensions, forming a repetitive grid, with $20 \mathrm{~m}$ wide streets.

The block buildings present different heights. This difference is due to the changes in the city ordinances during the years. The Land Plot Ordinance of 1860-1890 set a maximum height of $20 \mathrm{~m}$. The Ordinance of 1942-1976 increased the maximum height to $24.4 \mathrm{~m}$. The Metropolitan General Plan Ordinance of 1976 readdress the maximum height to $20.75 \mathrm{~m}$. As a result the Eixample district presents a discontinuous skyline, with a stepped geometry [9].

Considering the high density in the Eixample district, its current stepped skyline, the high levels of air contamination and the elevated difference in temperature with the periphery due to the UHI, this investigation seeks ways to re-naturalized the silhouette of the Eixample, through green roofs and vertical gardens while completing its broken skyline. 


\section{METHODOLOGY}

The investigation form part of a doctoral Project between the investigation group Integrated Architectural Research (IAR) from the University Ramon Llull and the Company La Casa por el Tejado (LTC).

The IAR is focused on the investigation of technical solutions of the Mediterranean architecture from a sustainable point of view.

LCT is a company that develops industrialized housing in high density cities. The company constructs industrialized penthouses off site, and places them on the roof top of existing buildings that are able to grow vertically, with the objective of taking advantage of the available surface to complete the skyline of the city. The main development of the company is in the Eixample district. This district has around 1,800 buildings that could grow vertically and about 65.2 ha of surface of roof tops and façades that can be naturalized [9].

In this context, the investigation is developed in real cases, these are professional projects which have been completed. The methodology comes from the analysis of the LCT projects, some of which have already been executed while others are still in the design phase. In order to propose green spaces and systems: such as partial walls and roof tops, and some intermediate spaces (terraces, balconies, galleries). Green infrastructures, which thanks to the prefabricated height-raising projects, allow to refurbish the common spaces of the building (patios, halls, stairs and façades).

In this way, the investigation analyzes the possible surfaces to be naturalized when adding the industrialized penthouses: roof tops, rear patios and communal walls. In order to find strategies of greening the silhouette of the city.

The next step of the investigation is to obtain information through interviews with architects and professionals that have intervened in LCT projects, to understand what they understand about greenery, which are the spaces and systems of naturalization implemented in the buildings, and the benefits and problems found in the integration of greenery in buildings.

Therefore, the analysis, the direct participation in the development of projects and the interviews enables us to define viable spaces of re-naturalization and to detect the main obstacles in the introduction of greenery.

\section{ANALYSIS}

\subsection{Building analysis}

The buildings in the Eixample blocks are characterized as presenting diverse surfaces with potential to be naturalized.

These buildings are constructed on a plan around a central patio for ventilation and illumination of the residential housing. They have a buildable depth that varies between 24 and $28 \mathrm{~m}$ and are 4-7 stories high. On the ground floor the interior part of plot is occupied by storage use. In this way, rear patios are found on the first floor of the buildings.

Due to the variation in the buildable depth and height, it is possible to see from the rear patios and from the top-roofs uncovered partial walls of different dimensions.

All these buildings conclude with a roof-top, which during the 20th century was used as a space for social meeting and nowadays have lost their use and have become empty surfaces.

These surfaces shape the urban skyline of the city and their naturalization could contribute to reducing the negative effects from the air pollution and the UHI in Barcelona, as well as to increase the quality of life of its inhabitants and activate disused surfaces. 
4.1.1 Party or shared walls

"A party wall is part of the skin of a structure that along with the façade conform the outer walls that contains the activities of a building. Unlike the façade, a dividing wall is not conceived to be visible, however as consequence of the urban layout changes, some of these walls are exposed to the view, these walls have not finish or aesthetic expression, showing a discontinuous image" [10].

In the Project Gran via 553, developed by LCT, the uncovered party walls are visible from the interior patios of the building and from the top-roof (Fig. 2). When the industrialized penthouse is placed on top pf the block, it is still possible to see up to $3 \mathrm{~m}$ of party wall from the new top-roof (Fig. 3). These surfaces have the potential to be naturalized through the implementation of vegetation.

Vegetation can be placed in cages, such as modular gabions that contain the substrate and plants and are hung from the dividing wall.
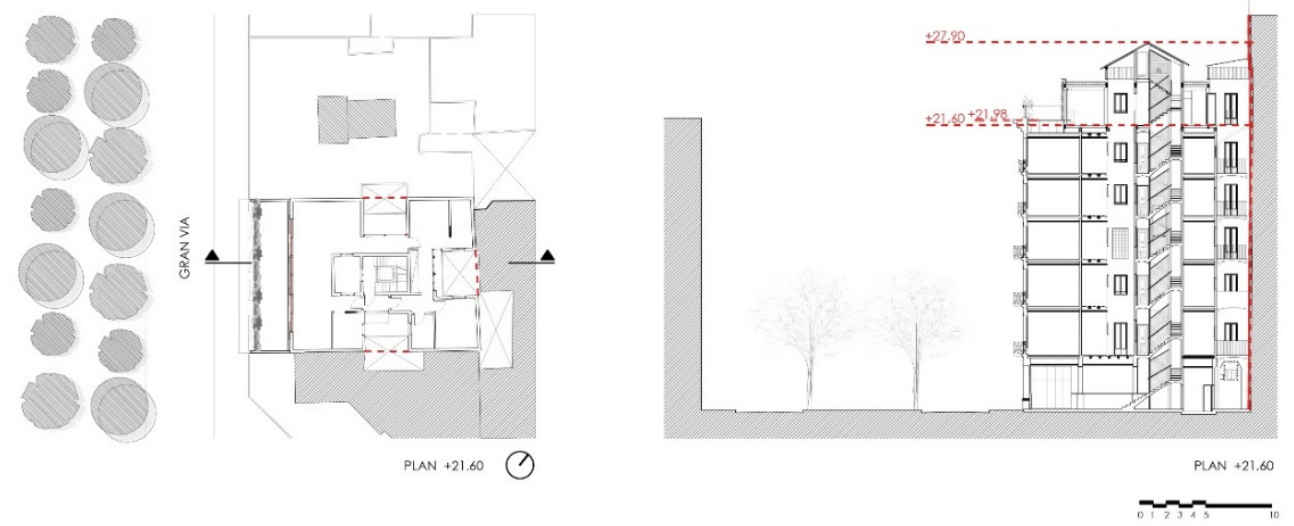

Figure 2: Project Gran Via 553, the project consists on a new penthouse with green balcony, and the restoration of the party walls and patio façades introducing green elements. (Source: F. Meignen, 2019.)

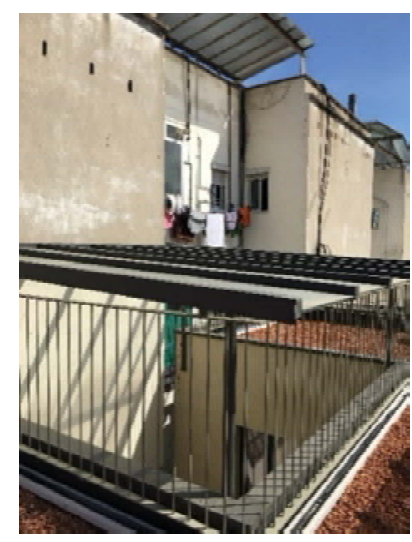

Figure 3: View of the party wall from the terrace of the building Gran Via 553. (Source: F. Meignen, 2018.) 
In this party wall it is possible to implement plant species with a high sun incidence requirement, for instance the geranium and begonia, whose flowers provide diverse colors and forms, or hanging species such as Hedera helix, with intense green colors during the whole year. This hanging plant is able to collect fine dust, particles $<5 \mu \mathrm{m}$, on its leaf surface during low water flow velocity, contributing to clean the air [11], [12].

\subsubsection{Roof tops}

"The roof top is the exterior part of a building; whose principal purpose is to protect the rest of the building. Roofs tops are flat roofs or slightly inclined, that enable dwellers to comfortably walk on them and that can be used to perform different activities (hanging clothes, sunbathing or reading...)" [13].

When a new penthouse is added, a new roof surface is placed on top of the existing structure. The project Roger de Llúria 41, the headquarters of LCT, is an industrialized penthouse with a green roof (Fig. 4).

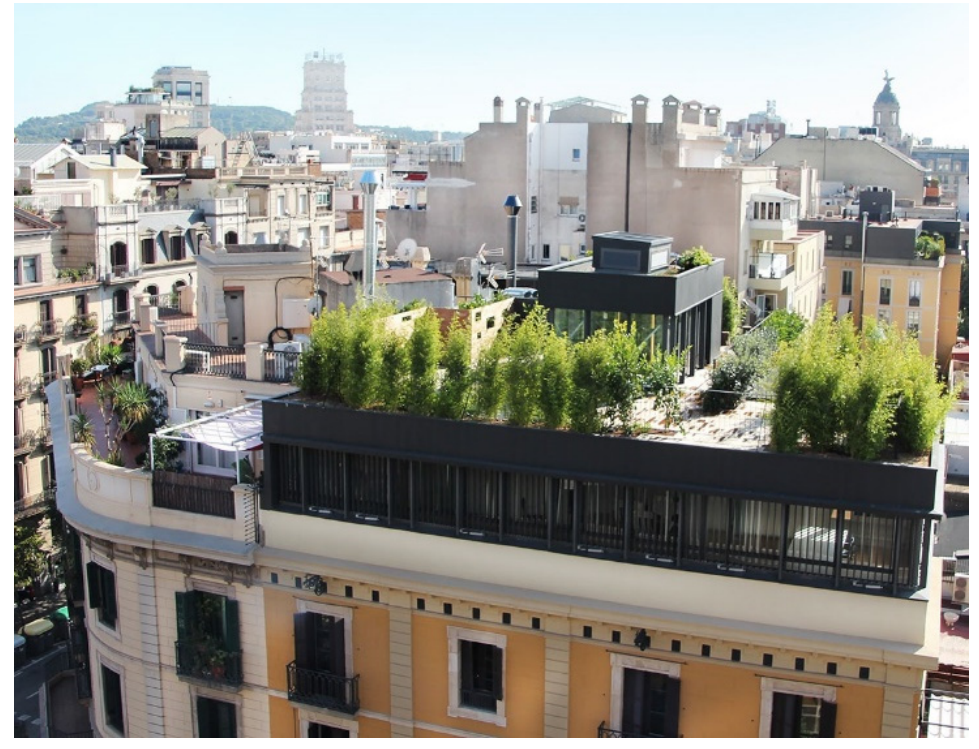

Figure 4: LCT headquarters. Penthouse with green roof. (Source: LCT, 2015.)

This green roof is made with a modular system of trays. These trays contain the substrate and the vegetation. Most of them are placed on the edges of the roof, which is the area with the highest load/bearing capacity, the flooring is made of a wooden platform supported by plots.

In this project the vegetation acts as a filter of views to the city. From this roof it is possible to see in the first plane the green of the shrubs and trees and in a second place the built environment of the city. It houses shrubs like Photinia fraserii, Viburnum tinus and Aloysia citriodora, small trees like Olea europaea and Citrus $\times$ limon, and a small urban garden with herbs such as Mentha $\times$ piperita, Rosmarinus officinalis and Ocimum basilicum.

This green surface presents temperatures between $1-4^{\circ} \mathrm{C}$ lower than conventional roofs, counter the UHI effects [14], acts a shelter for birds, bats and insects and provides a meeting space for the users [15]. 
Top-roofs not only have the potential to be covered with vegetation, they can also contain light structures such as greenhouses with urban gardens, which could benefit the production of vegetal products and the conservation of plants during winter, or pergolas covered with vine species.

\subsubsection{Rear patios}

The rear patios are open spaces enclosed by the party wall of the plots, which cover the uses occupied in the ground floor. Their principal purpose is the ventilation and illumination of the rear facades. Although their use is private, they can be seen from all the surrounding buildings.

In the project Rambla Catalunya 82 when the LCT intervention takes place, a new rear façade is added (Fig. 5). It consists of a gallery structure hanging from the attic, so it does not present any pillars at the rear patio. The patio measures $12 \times 15 \mathrm{~m}$, and it is visible from this gallery.

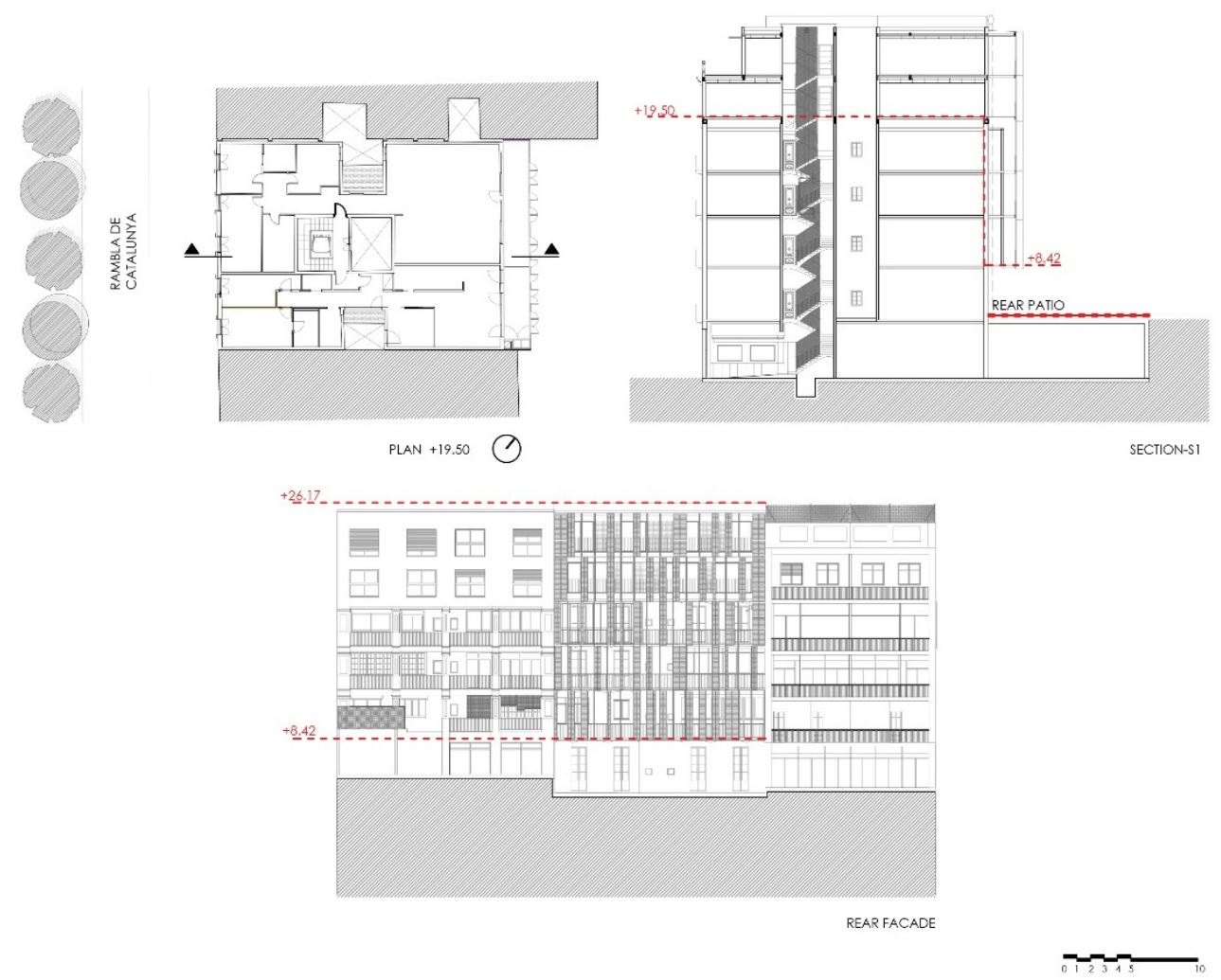

Figure 5: Project Rambla Catalunya 82. A new penthouse is built, and an extension of each floor through a new gallery. (Source: F. Meignen, 2019.)

In this way, the patio has the potential to be a green focal point, that could be naturalized through different plant species. In this case, vegetation is added in pots with small trees and shrubs, such as Euonymus japonicus, Plumbago auriculata, or Jasminum officinale. 
The rear patio could work as a green roof and it can house vegetation implementing the traditional systems with substrate and its different protection layers or with trays.

\subsection{Interviews}

Sixteen interviews were carried out with architecture companies that have executed height raising projects in existing buildings in the Eixample district with the company LCT.

The interviews consist in qualitative questions with the following narrative:

1. What do you think of when we talk about greenery?

2. Have you planned to integrate greenery in any of the project phases?

3. What are the benefits of implementing greenery in the building and in the city?

4. What are the main obstacles when implementing greenery in the projects?

Table 1: Summary table with interview results. (Source: F. Meignen, 2019.)

\begin{tabular}{|l|l|}
\hline \multicolumn{2}{|l|}{$\begin{array}{l}\text { What do you think of when we talk } \\
\text { about greenery? }\end{array}$} \\
\hline Positive emotions & $18 \%$ \\
\hline Intermediate spaces & $45 \%$ \\
\hline Design tool & $37 \%$ \\
\hline
\end{tabular}

\begin{tabular}{|l|l|}
\hline \multicolumn{2}{|l|}{$\begin{array}{l}\text { Have you planned to integrate greenery } \\
\text { in any of the project phases? }\end{array}$} \\
\hline Yes, greenery is integrable & $82 \%$ \\
\hline No, greenery is not integrable & $18 \%$ \\
\hline
\end{tabular}

\begin{tabular}{|l|l|}
\hline \multicolumn{2}{|l|}{$\begin{array}{l}\text { What are the benefits of implementing } \\
\text { greenery in the building and in the city? }\end{array}$} \\
\hline $\begin{array}{l}\text { Increase of green spaces for } \\
\text { social meeting }\end{array}$ & $7 \%$ \\
\hline Environmental benefits & $40 \%$ \\
\hline Improve aesthetic of buildings & $7 \%$ \\
\hline Improve biodiversity & $13 \%$ \\
\hline $\begin{array}{l}\text { Improve living intermediate } \\
\text { spaces }\end{array}$ & $33 \%$ \\
& \\
\hline
\end{tabular}

\begin{tabular}{|l|l|}
\hline \multicolumn{2}{|l|}{$\begin{array}{l}\text { What are the main obstacles when } \\
\text { implementing greenery in the projects? }\end{array}$} \\
\hline Maintenance & $34 \%$ \\
\hline Costs of execution & $14 \%$ \\
\hline $\begin{array}{l}\text { The opinion of the property } \\
\text { developer }\end{array}$ & $14 \%$ \\
\hline $\begin{array}{l}\text { The lack of knowledge of } \\
\text { greenery benefits }\end{array}$ & $14 \%$ \\
\hline Cultural problems & $8 \%$ \\
\hline $\begin{array}{l}\text { Lack of available space for } \\
\text { greenery in buildings }\end{array}$ & $8 \%$ \\
\hline $\begin{array}{l}\text { Lack of interest of the clients } \\
\text { in conserving green areas }\end{array}$ & $8 \%$ \\
\hline
\end{tabular}

According to the interviews, $45 \%$ of the designers imagine intermediate spaces (terraces, balconies, patios and decks) when talking about "green". 37\% of architects imagine "green" as a design tool. The other $18 \%$ imagine positive emotions (joy, comfort).

$82 \%$ of the architects consider that green is integrable from the beginning of the project. The other $18 \%$ do not consider it integrable, since its success will depend on its maintenance, which the buyer of the apartment is not necessarily interested in carrying out.

Regarding the benefits of greenery, the interviews show that $40 \%$ consider that the benefits are more focused on the environment, $\mathrm{CO}_{2}$ absorption, air cleaning and pollutants. $33 \%$ think that inhabiting and experiencing the intermediate spaces improves through the implementation of green. $13 \%$ see benefits in the field of biodiversity. $7 \%$ of the designers consider that implementing vegetation in intermediate spaces generates more green areas for 
social gathering and recreation, while another $7 \%$ believe that green in intermediate spaces improves the aesthetics of buildings.

Regarding the impediments, $34 \%$ of the architects consider that maintenance is one of the biggest problems, because vegetation is a living being that requires care, irrigation and pruning. $14 \%$ of the interviewers considered the costs of execution as an impediment, since the budget normally prioritizes other issues, and green is usually seen as an expensive element that is not essential. Another $14 \%$ considerer the promoter's mentality as an obstacle that greatly limits the implementation of green areas in intermediate spaces, the promoters look for the maximum percentage of marketable areas, in this way, the intermediate spaces are minimized to the maximum. 14\% of interviewers believe that the lack of knowledge about the benefits of green is also an impediment, society ignores or does not value the possibilities and benefits generated by green. In a smaller percentage, some architects consider as an impediment the weight of overload that the substrate of plants can have in the structure ( $8 \%)$, the lack of spaces in the building (8\%), and a personal issue of the client (8\%) since many buyers are not interested in conserving a green intermediate space so it could generate problems in the sales process.

\section{DISCUSSION AND CONCLUSIONS}

Although there are many difficulties when implementing greenery in building and in the city, most of the interviewers considered that greenery could be integrable in buildings and associated it with benefits for the environment and the quality of life in general.

In this way, it is possible to think that these prefabricated height-raising projects in addition to completing the skyline of the city are able to re-naturalize the urban silhouette including greenery in theirs roof, rear patios and exposed party walls through modular structures such as trays or gabions that contain vegetation, as well as greenhouses or pergolas on roof tops covered with hanging plants. They could work as vivid examples of the benefits of implementation of greenery in the city, mitigating the noise and air pollution, countering the effect of the UHI by refreshing the temperature with plants, generating interest and a new conscience in the community to introduce nature in the existing infrastructures and improving the aesthetic of the city. The re-naturalization strategies of the urban skyline can be also extrapolated to other Mediterranean cities taking advantage of the available existing surfaces.

\section{REFERENCES}

[1] Barcelona City Council, Gaseta Municipal Butlletí Oficial de l'Ajuntament de Barcelona. Ayuntament de Barcelona: Barcelona, 2018.

[2] Barcelona City Council, Barcelona activa data sheet. Ayuntament de Barcelona: Barcelona, 2018.

[3] Barcelona City Council, Programa de mesures contra la contaminació de l'aire. Ayuntament de Barcelona: Barcelona, 2016.

[4] Barcelona Field Study Centre, Barcelona urban pollution. https://geographyfieldwork.com/BarcelonaPollution1.htm. Accessed on: 28 May 2019.

[5] Rojas-Cotoreal, G., Navés, F., Peña, J., Roset, J. \& López-Ordoñez, C., Climate and Urban Morphology in the City of Barcelona: The Role of Vegetation, Mediterranean Identities, pp. 365-380, 2017.

[6] Barcelona City Council, Barcelona green infrastructure and biodiversity plan 2020. Medi Ambient i Serveis Urbans - Hàbitat Urbà. Ajuntament de Barcelona: Barcelona, 2018. 
[7] Direcció de Serveis Ambientals de l'AMB, La isla de calor en el área metropolitana de Barcelona y la adaptación al cambio climático. AMB: Barcelona, 2015.

[8] Ajuntament de Barcelona, L'Eixample.

https://ajuntament.barcelona.cat/eixample/es/el-distrito-y-sus-barrios/el-distrito-ysus-barrios. Accessed on: 1 Jun. 2019.

[9] Artés, J., Wadel, G. \& Martí, N., Vertical extension and improving of existing buildings. The Open Construction Building Technology Journal, 10, pp. 33-55, 2016.

[10] Contreras, E., Las medianeras de Barcelona. Master's thesis, Universidad de Barcelona, 2014.

[11] Collier, M., Gölsdorf, K. \& Müller, H., Green walls for clean air. Planning for Resilient Cities and Regions Conference, Joint AESOP/ACSP Congress, Dublin, 2013.

[12] Green Roofs for Healthy Cities, Introduction to green walls technology benefits and design.

[13] Barcelona City Council, Guía de azoteas y cubiertas verdes. Ayuntamiento de Barcelona: Barcelona, 2015.

[14] United State Environmental Protection Agency, Using green roof to reduce heat islands. www.epa.gov/heat-islands/using-green-roofs-reduce-heat-islands. Accessed on: 29 Jun. 2019.

[15] White, E. \& Gatersleben, B., Greenery on residential buildings: Does it affect preferences and perception of beauty? Journal of Environmental Psychology, 31, 2011. 